
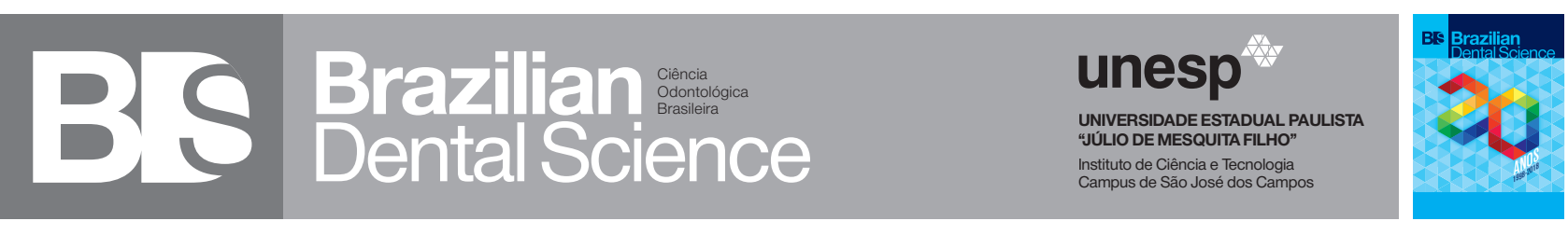

\title{
Effect of the mixing method on the dimensional stability of dental stones
}

\author{
Efeito do método de mistura na estabilidade dimensional de gessos odontológicos
}

Rubens Nisie TANGO ${ }^{1}$, Diego Leonardo Aparecido SOUZA', Lucas Hian da SILVA², Tabata do Prado SATO ${ }^{1}$, Alexandre Luiz Souto BORGES $^{1}$, Paula Carolina Komori de CARVALHO ${ }^{1}$

1 - São Paulo State University (Unesp) - Institute of Science and Technology, São José dos Campos - Department of Dental Materials and Prosthodontics - São José dos Campos - SP - Brazil.

2 - Private Office - São José dos Campos - SP - Brazil.

3 - Universidade Cidade de São Paulo - São Paulo - SP - Brazil.

\section{ABSTRACT}

Objective: The aim of this study was to evaluate the influence of mixing method and the empiric water/powder ratio on the dimensional change of two types of dental stones (type III and type IV) at different setting times: baseline, loss of brightness, initial and final setting ( $1 / 4$ and 1pound Gilmore's needle, respectively) and, after 48 hours at $37^{\circ} \mathrm{C}$. Material and Methods: Five mixing methods were used: Gc - manufacturer's recommendation, G1 - weighed powder/ empiric water volume and powder on water, G2 - weighed powder/ empiric water volume and water on powder, G3 - empiric powder volume, graduated water and powder on water, G4 - empiric powder volume, graduated water and water on powder. The linear expansion was measured according to ISO 6873. The expansion values $\left(\mathrm{x} 10^{-2} \mathrm{~mm}\right)$ were analyzed by Two-way ANOVA and Tukey HSD test $(\alpha=0.05)$. Results: For type III, the results showed significance for both factors and for interaction; for type IV, only the time were significant $(p<0.05)$. Limited by methodology, it could be concluded that both dental stones expanded more than the recommended by ISO. Conclusion: The expansion of type III was dependent on the mixing method, and once correct consistency is reached with type $\mathrm{IV}$, there is no influence of mixing method on dimensional stability.

\section{KEYWORDS}

Gypsum; Dental stones; Expansion behavior.

\section{RESUMO}

Objetivo: O objetivo deste estudo foi avaliar a influência do método de mistura e da relação empírica de água/pó na alteração dimensional de dois tipos de gessos odontológicos (tipo III e tipo IV) em diferentes tempos de trabalho: baseline, perda de brilho, inicial e final (agulha de Gilmore de 1/4 e 1 libra, respectivamente) e, após 48 horas a $37^{\circ}$ C. Material e Métodos: Cinco métodos de mistura foram utilizados: Gc - recomendação do fabricante, G1 - pó pesado / volume empírico de água e pó na água, G2 - pó pesado / volume empírico de água e água no pó, G3 - volume empírico de pó, água graduada e pó na água, G4 - volume de pó empírico, água graduada e água no pó. A expansão linear foi medida de acordo com a norma ISO 6873 (1998). Os valores de expansão ( $\mathrm{x} 10^{-2} \mathrm{~mm}$ ) foram analisados pelo teste ANOVA dois fatores e teste de Tukey HSD $(\alpha=0,05)$. Resultados: Para o tipo III, os resultados mostraram significância para ambos os fatores e para interação; para o tipo IV, apenas o tempo foi significativo $(\mathrm{p}<0,05)$. Limitado pela metodologia, pode-se concluir que ambos os gessos odontológicos expandiram mais do que o recomendado pela ISO. Conclusão: A expansão do tipo III foi dependente do método de mistura e, uma vez atingida a consistência correta com o tipo IV, não há influência do método de mistura na estabilidade dimensional.

\section{PALAVRAS-CHAVE}

Gesso; Gesso odontológico; Comportamento de expansão. 


\section{INTRODUCTION}

$\mathrm{D}$ espite the digital technology for virtual cast construction, dental stones are still widely used in Dentistry for different applications in private offices and in laboratories for cast construction, and for mounting casts in articulator. [1-3] Its popularity can be explained by its low price, ease of handling and ability to produce reliable results. [4]

The type III and IV stone are $\alpha$-hemihydrates, which present smaller and compact grain size, a more ordinate crystalline grid, resulting in a lower water/powder ratio, in a lower setting expansion and, higher mechanical strength compared to the $\beta$-hemihydrates (type II stone).

Dental stones handling characteristics have been studied aiming to reduce the setting expansion, thus providing higher accuracy in casts. Manufacturers recommend the weighing of powder, to measure the water in a test tube and, to pour the powder on water. If possible, this should be performed in a vacuum mixer machine to decrease air incorporation in the mass. But, this procedure is time consuming. In daily practice professionals use to mix gypsum under tap water, adding water and/or gypsum powder repeatedly in the attempt to reach the wright consistency, which in many cases is not obtained. This empiric agglutination leads to flaws in the mass and to dimensional alteration of the cast. [5]

The aim of this study was to evaluate the influence of mixing method, and the empiric water/powder ratio on the dimensional stability of two types of dental stones. The null hypothesis is that the mixing method and empiric water/ powder ratio will not influence on dental stone dimensional stability.

\section{MATERIAL AND METHODS}

Two types of dental stones, a type III (Herodent ${ }^{\circledR}$, Vigodent S / A., Rio de Janeiro, $\mathrm{RJ}$, Brazil) and a type IV (Durone ${ }^{\circledR}$, Dentsply, Petrópolis, RJ, Brazil) were tested according to ISO 6873 (1998) for linear dimensional change. The specimens were divided into five groups for each type of gypsum $(n=5)$. The groups were divided as follows:
- Control Group (CG): The manipulation was carried out according to the manufacturers' instructions (powder poured on water). The powder (100 g) was previously weighed on an electronic scale (JB Ind. e Com, Sao Paulo, Brazil), and distilled water (33 $\mathrm{ml}$ and $19 \mathrm{ml}$, for type III and type IV, respectively) measured in a tester tube.

- Group I (G1): a rubber mixing bow received marks on its internal wall, according to the manufacturers' recommended water volumes (33 $\mathrm{ml}$ /type III and $19 \mathrm{ml} /$ type IV). The water was measured in this bow and, the powder weighed as in CG. The manipulation was carried out according to the manufacturers' instructions.

- Group II (G2): powder and water were measured as in CG, but manipulation was waterpoured on powder.

- Group III (G3): the water was measured with the market rubber bow and powder was poured on water until working consistency was obtained.

- Group IV (G4): the powder was weighed as in CG and water was poured until working consistency was obtained.

All specimens were prepared by only one operator, previously trained and calibrated for obtaining the working consistency of dental stones. Specimens were obtained by handmixingduring 60s with circular movements with approximately $180 \mathrm{rpm}$. The mixture was then poured into a $\mathrm{V}$-shaped mold, which was part of an expansion-measuring device. The mold was lined with a polytetrafluoroethylene - PTFE film. The dial gauge attached to the device was calibrated to $0.01 \mathrm{~mm}$. After mold filling, the dimensional changes were measured at four different times:B - baseline (right after mold filling); L - loss of brightness; I - initial setting time (Gilmore needle $1 / 4$ pound);F- final setting time (Gilmore needle 1 pound)and, 48 - after 48 hours at $37^{\circ} \mathrm{C}$.

For each type of dental stone, the values of linear dimensional change $\left(\mathrm{x}^{-2} \mathrm{~mm}\right)$ were submitted to Split plot 2-way ANOVA and to Tukey HSD test ( $\alpha=0.05$ ). 


\section{RESULTS}

The ANOVA for the type III gypsum showed significance for two factors (time and mixing) and for the interaction $(\mathrm{p}<0.05)$ (Table 1$)$.

Table 1- Results of 2-way ANOVA for type III gypsum expansion

\begin{tabular}{|cccccc|}
\hline Effect & DF & SS & MS & F & p \\
\hline Mixing & 4 & 5.4725 & 1.36812 & 11.2251 & 0.000000 \\
\hline Time & 4 & 107.6717 & 26.91792 & 220.8559 & 0.000000 \\
\hline MixingX Time & 16 & 15.2635 & 0.95397 & 7.8271 & 0.000000 \\
\hline Error & 100 & 12.1880 & 0.12188 & \\
\hline
\end{tabular}

The expansion was similar for the different groups when measured at initial and final setting time (1/4 pound and 1 pound, respectively). For $48 \mathrm{~h}, \mathrm{GC}$ and G2 presented the lowest expansion values, G1 and G3 the highest and, G4 intermediate values. For GC, G1 and G2 further expansion was noted only after 48 hours (Table 2 ).

Table 2 - Results of Tukey HSD test for type III gypsum expansion (mm)

\begin{tabular}{cccccc} 
& \multicolumn{5}{c}{ Dimensional Change } \\
& B & L & I & F & $\mathbf{4 8}$ \\
CG & $0.00 \pm 0.00 \mathrm{~A}, \mathrm{a}$ & $0.00 \pm 0.00 \mathrm{~A}, \mathrm{a}$ & $0.16 \pm 0.35 \mathrm{~A}, \mathrm{a}$ & $0.54 \pm 0.43 \mathrm{~A}, \mathrm{~b}$ & $1.00 \pm 0.86 \mathrm{~B}, \mathrm{~b}$ \\
G1 & $0.00 \pm 0.00 \mathrm{~A}, \mathrm{a}$ & $0.00 \pm 0.00 \mathrm{~A}, \mathrm{a}$ & $0.10 \pm 0.10 \mathrm{~A}, \mathrm{a}$ & $0.68 \pm 0.40 \mathrm{~A}, \mathrm{~b}$ & $2.92 \pm 0.35 \mathrm{D}, \mathrm{d}$ \\
G2 & $0.00 \pm 0.00 \mathrm{~A}, \mathrm{a}$ & $0.00 \pm 0.00 \mathrm{~A}, \mathrm{a}$ & $0.00 \pm 0.00 \mathrm{~A}, \mathrm{a}$ & $0.68 \pm 0.19 \mathrm{~A}, \mathrm{~b}$ & $1.88 \pm 0.74 \mathrm{C}, \mathrm{c}$ \\
G3 & $0.00 \pm 0.00 \mathrm{~A}, \mathrm{a}$ & $0.00 \pm 0.00 \mathrm{~A}, \mathrm{a}$ & $0.00 \pm 0.00 \mathrm{~A}, \mathrm{a}$ & $1.18 \pm 0.44 \mathrm{~B}, \mathrm{c}$ & $3.46 \pm 0.43 \mathrm{D}, \mathrm{d}$ \\
G4 & $0.00 \pm 0.00 \mathrm{~A}, \mathrm{a}$ & $0.00 \pm 0.00 \mathrm{~A}, \mathrm{a}$ & $0.00 \pm 0.00 \mathrm{~A}, \mathrm{a}$ & $1.20 \pm 0.23 \mathrm{~B}, \mathrm{c}$ & $2.74 \pm 0.79 \mathrm{D}, \mathrm{d}$
\end{tabular}

Different capital letters in rows and small case letters in colunms represent significant statistical difference according to Tukey HSD test ( $p<0.05)$.

No dimensional change was noticed until gypsum brightness loss.

For the type IV gypsum, ANOVA showed significance only for the time $(\mathrm{p}<0.05)$ (Table 3$)$.

Table 3 - Results of 2-way ANOVA for type IV gypsum expansion

\begin{tabular}{|c|ccccc|}
\hline Effect & DF & SS & MS & F & p \\
\hline Mixing & 4 & 0.04202 & 0.010506 & 0.7488 & 0.560868 \\
\hline Time & 4 & 29.41437 & 7.353593 & 524.1222 & 0.000000 \\
\hline MixingX Time & 16 & 0.08304 & 0.005190 & 0.3699 & 0.986686 \\
\hline Error & 110 & 1.5433 & 0.014030 & \\
\hline
\end{tabular}


The specimens showed no dimensional change until initial setting time ( $1 / 4$ pound) (Table 4).

Table 4 - Results of Tukey HSDs test for type IV gypsum expansion (mm).

\begin{tabular}{|cc|}
\hline Group & Dimensional Change \\
\hline Initial & $0.00 \pm 0.00 \mathrm{~A}$ \\
\hline Brightness Loss & $0.00 \pm 0.00 \mathrm{~A}$ \\
\hline Initial Setting & $0.00 \pm 0.00 \mathrm{~A}$ \\
\hline Final Setting & $0.06 \pm 0.08 \mathrm{~A}$ \\
\hline 48 hours & $1.14 \pm 0.22 \mathrm{~B}$ \\
\hline
\end{tabular}

Different capital letters in colunm represent significant statistical difference according to Tukey HSD test $(p<0.05)$.

\section{DISCUSSION}

The null hypothesis was partially accepted. For type III, all the factors (water/ powder ratio, time and the interaction) were significant, but for the type IV gypsum only the interaction was significant (Tables 1 and 3). Although all groups the standards have been followed as planned, in almost all the setting expansion was greater than that recommended by the specification No. 25 of the American Dental Association (ADA, 1981) for the respective type of plaster tested. [7]

This volume increase is due to the expansive growth of crystals from the crystallization nuclei, causing pushing forces, thus overcoming the surface tension of water and causing the increase in volume, grounded theory by Le Chatelier. [6]

Heshmati et al., have stated that the setting expansion can occur for up to 120 hours after manipulation of the cast. [7] In contrast, according to Michalakis et al. (2009) the expansion occur up to 96 hours. [8]

Clinically, it is known that an increased mixing time and a low water/ powder ratio tend to reduce the setting time and to increase the expansion of dental gypsum [9]. In 2000, Ferreira et al. determined the magnitude of the expansion of some types of dental gypsums (type III, type IV and type V). [3] As in the present study authors showed that the setting expansion was greater than ISO 6873 for all tested groups.

Lopes et al., in 2003, evaluated the effect of different types of dental gypsum and its hydration on position alteration on an articulator. [10] The results indicated that accuracy was higher for the special type of gypsum, justifying its use for casting and, when high mechanical strength is required. Alberto et al. studied the influence of a different water/powder ratio in the dimensional and thermal change of a Type 4 gypsum (high strength gypsum) [11]. They found that minimal differences in water/powder ratio may result in significant differences in values for both parameters.

Azer et al. studied the influence of mixing methods on physical properties of dental stones, types IV and V [4]. They compared the manipulation mode by vacuum mechanical mixing or hand mixing. The results about dimensional change were not significant for both gypsum tested on the study.

And Shahi et al. [12] presented a positive effect of the ultrasonic mixing technique on some important properties, such as increased working time and a decreased setting time.

\section{CONCLUSION}

Limited by methodology, it could be concluded that both dental stones expanded more than the recommended by ISO. The expansion of type III was dependent on the mixing method, and once correct consistency is reached with type $\mathrm{IV}$, there is no influence of mixing method on dimensional stability.

\section{REFERENCES}

1. Motta R. Materiais Dentários. 2 ed. Niterói: Universidade Federal Fluminense; 1979.

2. Anusavice K. Materiais Dentários. 11 ed. Rio de Janeiro: Elsevier;2005.

3. Ferreira AR, Henrique J, Pinto N. Determinação da magnitude de expansão de alguns tipos de gesso. Salusvita. 2000:19(2);29-39.

4. Azer SS, Kerby RE, Knobloch LA. Effect of mixing methods on the physical properties of dental stones. J Dent. 2008 Sep;36(9):736-44. doi:10.1016/j. jdent.2008.05.010. Epub 2008 Jun 26.

5. Pereira T, Santos Junior GC, Rubo JH, Ferreira PM, Valle AL. Gesso tipo 
iv: influência das técnicas de manipulação. Rev Fac Odontol Bauru. 2002;10(3):150-5.

6. Le Chatélier H. Recherches expérimentales sur la constitution des mortiers hydrauliques. Paris; Dunod: 1887.

7. Heshmati RH, Nagy WW, Wirth CG, Dhuru VB. Delayed linear expansion of improved dental stone. JProsthet Dent. 2002 Jul;88(1):26-31.

8. Michalakis KX, Stratos A, Hirayama H, Pissiotis AL, Touloumi F.Delayed setting and hygroscopic linear expansion of three gypsum products used for cast articulation. J Prosthet Dent. 2009 Nov;102(5):313-8. doi:10.1016/ S0022-3913(09)60181-5.

9. Van Noort. Introdução aos Materiais Dentários. 2 ed. Porto Alegre: Artmed; 2004.
10. ArturLLopes Z Cezero LD. Precisão na montagem em articulador em função do tipo de gesso e tratamento do modelo. Braz Dent Sci. 2003:6(2);65-71. doi: http://dx.doi.org/10.14295/bds.2003.v6i2.356

11. Alberto N, Carvalho L, Lima H, Antunes P, Nogueira R, Pinto JL. Characterization of different water/powder ratios of dental gypsum using fiber Bragg grating sensors. Dent Mater J. 2011;30(5):700-6. Epub 2011Sep 23.

12. Shahi S, Ghasemi N, Rahimi S, Yavari H, Janani M, Mokhtari H, et al. The Effect of Different Mixing Methods on Working Time, Setting Time, Dimensional Changes and Film Thickness of Mineral Trioxide Aggregate and Calcium-Enriched Mixture. Iran Endod J. 2015 Fall;10(4):248-51. doi: 10.7508/ iej.2015.04.008

\section{Tabata do Prado Sato}

(Corresponding address)

Departamento de Materiais Odontológicos e Prótese, Instituto de Ciência e Tecnologia, Universidade Estadual Paulista Júlio de Mesquita Filho - UNESP, Av. Eng. Francisco José Longo, 77, São José dos Campos, SP, 12245-000, Brazil. Tel.:+55 1239479407. 